\title{
The implementation of regional policy on the establishment of local public companies against local own-source revenue
}

\author{
H Budiman' ${ }^{1}$ E Yuhandra ${ }^{2}$, A Riyanto ${ }^{3}$, T Tendiyanto ${ }^{4}$ \\ Faculty of Law, Universitas Kuningan, Indonesia
}

Email : haris.budiman@uniku.ac.id

\begin{abstract}
Kuningan District has tremendous tourism potential. If this potential is managed properly, it will provide a significant income for the regional treasury which can then increase the local own-source revenue. This study aims to analyze the implementation of regional policy on the establishment of local public companies which is expected to contribute to the increase of local own-source revenue. The method used in this study was a non-doctrinal research method with a sociologic approach. As results, it was revealed that the establishment of local public companies has not yet contributed optimally in increasing local own-source revenue due to several factors, including; 1) substantial factors - the shifted status of Mount Ciremai from a protected forest to a national park has narrowed the space for tourist attractions in Kuningan District; 2) structural factors facilities and infrastructures owned by the local public company have not yet been adequate to support the management of tourist attractions in Kuningan District; and 3) cultural factors - the culture of the surrounding community has not yet support a modern and professional tourism management as it is considered contrary to the beliefs and the vision of Kuningan as a Conservation District.
\end{abstract}

Keywords: regional policy; tourism management; Kuningan

\section{Introduction}

The fourth paragraph of the preamble to the 1945 Constitution describes that the purposes of the state of Indonesia are to improve public welfare, to educate the life of the people, and to participate towards the establishment of a world order based on freedom, perpetual peace, and social justice. This indicates that the state of Indonesia is a welfare state. In a welfare state, the state or the government is not only responsible to ensure public security and order, but is also responsible to realize social justice, public welfare, and the greatest prosperity of the people [1]. Law of the Republic of Indonesia No. 23 of 2014 concerning Regional Government explains that regions as legal community units have the authority to regulate and manage their territories according to the aspirations and interests of the surrounding community as long as they do not conflict with the national legal order and public interest. The principle of regional autonomy uses the broadest principle of autonomy, namely formulating regional policies to provide services, to increase participation, and to empower the community aiming at improving people's welfare. Therefore, since the enactment of regional autonomy, regions have tried various ways to manage and make use of the spatial structure they have in order to improve people's welfare. 
According to Law No. 23 of 2014 on Regional Government, the purpose of regional autonomy is to realize community's welfare by improving the quality of services, empowering the community, and providing proper facilities and infrastructures in the regions. One of the efforts that the regional governments can make to achieve this purpose is by making various policies to explore various potentials and resources they have for the purpose of people's welfare [2]. In this regional autonomy era, regions are given greater authority to regulate and manage their own households. With the enactment of regional autonomy, it is expected that each region is able to manage its own region and to compete with other regions so that the regional governments can serve the community well based on the applicable regulations and cultural values.

Besides, one of the purposes of regional autonomy is to bring government services closer to the community and to make it easier for the community to monitor and control the use of funds coming from the Regional Budget Revenues and Expenditures (APBD). Hence, Regional Government is expected to be able to explore financial sources in order to meet the needs of government households and development through local own-source revenue. [3] Establishing local public companies in the form of Regional-Owned Enterprises (BUMD) can be one of financial sources for regions. The establishment of local public companies by the Regional Government is based on the provisions of Article 402 paragraph (2) of Law No. 23 of 2014 on Regional Government and Article 139 paragraph (1) of Government Regulation No. 54 of 2017 on Regional-Owned Enterprises. Local public companies established by the Regional Government are very diverse, both in terms of their types, their field of businesses, and their conditions.

Yet, in several regions, the existence of these local public companies does not much contribute to local own- source revenue or even becomes a bad record in regional government systems [4]. Therefore, the establishment of a local public company must have a clear purpose because the regional government is not a business actor, but it is the one responsible to carry out development and provide services to the community. However, as the establishment of local public companies requires a sufficiently large amount of capital, its existence must be aimed at supporting regional development and community services or even providing benefits for regional finances [5]. Based on the description, this case study tries to analyze the implementation of regional policy on the establishment of Various Businesses Local Public Company (Perumda Aneka Usaha) against local own-source revenue in Kuningan District, Indonesia.

\section{Method}

This present study employed a non-doctrinal research method. It is because, in this study, law is not only conceptualized as the principles and rules governing human life in society, but also includes the institutions and the processes that make these principles applicable in society. Thus, this study tried to identify the relationship between legal factors and extra-legal factors related to the topic under study [6]. 


\section{Result and Discussion}

\subsection{Kuningan district policies on the establishment of local public companies}

Economic development carried out by a country must be seen as a planned, programmed, systematic, and sustainable effort in increasing the welfare and the quality of life of all citizens. According to Friedmann, there are four functions of the State in the economic field, namely as a guarantor of the people's welfare, as a regulator, as an entrepreneur running certain sectors through state-owned enterprises, and as a supervisor formulating fair standards regarding the performance of economic sectors to fulfill responsibilities of the regions to the community. [7] The main characteristic showing that an autonomous region is able to be autonomous lies in its financial capacity. It means that autonomous regions must have the authority as well as the ability to explore their own financial sources, and to manage and use their own finances to finance regional administration.

Increasing local own-source revenue through the management of regional resources can be done by establishing Regional-Owned Enterprises (BUMD). The establishment of BUMD is expected to increase local own-source revenue in order to realize the greatest prosperity of the local community. Therefore, local public companies cover various fields of development, including agribusinesses, strategic industries, constructions, properties, services/trade, telecommunications, transportations (land, sea, and air transportations), energy and mineral resources, marine and fisheries, tourism, infrastructures, investments, banking, insurance, and other businesses.

One of the efforts made by Kuningan District Regional Government to increase local ownsource revenue is by making policy in the form of establishing Local Public Companies (Perumda). One of Local Companies established based on Regional Regulation No. 8 of 2009 as amended by Regional Regulation No. 11 of 2019 was the Various Businesses Local Company (Perusahaan Daerah Aneka Usaha/PDAU). The change from Local Company to Local Public Company is a response to the issuance of Government Regulation No. 47 of 2017 on RegionalOwned Enterprises (BUMD). Hence, there was a change in the name of the Various Businesses Local Company (PDAU) to the Various Businesses Local Public Company (Perumda Aneka Usaha). The establishment of local public companies aims to support regional development, to participate in national economic development, to strengthen and improve the quality of businesses and markets for community products, to strengthen and improve the quality of community economic institutions, to encourage healthy market mechanisms, to encourage increased people's purchasing power, and to encourage the openness of market information, with the types of business in information and communication technology, energy, agribusiness, tourism, agriculture, plantation, livestock, trade, construction, and various services.

In this regional regulation, Perumda Aneka Usaha is given the authority to manage the resources owned by Kuningan District, including in the fields of energy, agribusiness, trade, agriculture, livestock, plantation, construction, tourism, and various other businesses. However, due to various limitations, there are only a few businesses that have been carried out, including bottled water production, towers establishment, petroleum refining, property, trade, event organizer (EO), and tourism. In its implementation, only tourism sector that can provide benefits for the increase of local own-source revenue. The eight tourist attractions managed by Perumda Aneka Usaha include Waduk Darma, Balong Cigugur, Balong Dalem, Cibeureum, Cipaniis, Cipaniis Singkup, Telaga Remis, and Telaga Nilem.

Yet, in fact, the local own-source revenue of Kuningan District is still low. According to 2019 Data, local own-source revenue (PAD) of Kuningan District was 346 billion with Regional Budget Revenues and Expenditures (APBD) of 2.8 trillion. It means that the contribution of 
PAD to APBD does not reach $20 \%$ as the basis for regional independence. Therefore, Kuningan District still relies on general allocation funds and balance funds from the central government. This issue has certainly become an obstacle for regional government in their efforts to improve people's welfare. Whereas, in this regional autonomy era, regions need to be creative in finding and exploring their own potential in organizing and managing their own households. [8]

The changes of policies in the field of information and technology requires Perumda Aneka Usaha to open new tourism places as well as new businesses. One of the policies affecting Perumda Aneka Usaha is the shifted status of Mount Ciremai from a protected forest to a national park (Taman Nasional Gunung Ciremai/TNGC). As a result, some of tourist-attractions that are previously managed by Perumda Aneka Usaha are now included into TNGC area and some other tourist attractions are no longer productive. One of considerations of Perumda Aneka Usaha to open new tourism attractions is that the management of the new tourism attractions is more flexible as they are not included to the Mount Ciremai National Park (TNGC) area so that Perumda Aneka Usaha can maximize new facilities and can reduce the price of entrance tickets.

The results of the study showed that the realization of revenue from Perumda Aneka Usaha in Kuningan District during the last five years had never reached the target set. This implies that the performance of Perumda Aneka Usaha needs to be improved by setting reasonable targets based on the real potential of each business service managed by Perumda Aneka Usaha. The contribution of local public companies to local own-source revenue in Kuningan District is relatively small and is even unable to contribute at all in the last five years (2015-2019). It is because the management of local companies has not been optimal. In fact, one of the goals of the establishment of local companies is to become a source of local own-source revenue. [9]

This finding is in line with Cahyaningrum's study [10] which found that the management of Regional Owned Enterprises (BUMD) becomes a widely discussed issue as there is a number of BUMD whose conditions are still quite bad. Most BUMD throughout Indonesia still rely on the Regional Budget Revenues and Expenditures (APBD) for its operations. Perumda Aneka Usaha of Kuningan District is a local company whose ownership is $100 \%$ owned by the Kuningan District Regional Government with the authorized capital projected more than IDR 17 billion. As of 2018, the Kuningan District Regional Government has given more than IDR 9.4 billion capital to PDAU. From the data, it was found that in the 2018 APBD realization report, PDAU Kuningan was only able to contribute IDR 4.6 million to PAD from the target of IDR 173.7 million (2.69\%). This data is so frustrating so that there is a plan to disband this local public company. [11]

The low business quality of Perumda Aneka Usaha is a result of its management system which was not based on good corporate governance. Currently, Perumda Aneka Usaha tries to make various innovations in order to contribute to the increase of local own-source revenue. Some of the innovations done are the construction of supporting facilities and infrastructure, the establishment of organizations and tourism business units, and the application of a cashless payment system installed at various tourist attractions under the management of Perumda Aneka Usaha. This cashless payment system can provide more transparent data banking services and reduce the circulation of physical money. This innovation is expected to improve people's welfare and to increase the accountability of the company as the financial system has been centralized.

Although the opening of new tourism attractions takes a quite long time and has its own obstacles, but it is expected that the opening can support the advancement of Perumda Aneka Usaha as well as can contribute to the increase of local own-source revenue. To increase local own-source revenue, Perumda Aneka Usaha promotes tourist attractions through various social media, such as Instagram, Facebook, and Website. The promotion through social media is done 
because the target is young people. The effort done by Perumda Aneka Usaha to help regional government to increase local own- source revenue (PAD) through regional tourism sector is basically not a breakthrough because regional tourism sector has been a source of local ownsource revenue for a long time. Therefore, regional government is required to be able to manage sources of local own-source revenue optimally. Data from Regional Financial Audit Board (BPK) shows that the local own-source revenue of Kuningan District in 2019 is still originated from local taxes with amount of IDR 331.000.000.000, while tourism sector managed by Perumda Aneka Usaha only contributes IDR 173.795.322 of the target of Rp. 595.123.000. Hence, it can be seen that the contribution of Regional Retribution from tourism sector is quite low so that there is no significant effect on the local own-source revenue of Kuningan District. [12]

The low local own-source revenue is a result of the lack contribution of tourism sector. Although tourism sector is not a major source of local own-source revenue, but an increase in local own-source revenue can occur if this sector is well managed. Up to now, Perumda Aneka Usaha only manages eight tourist attractions, namely Waduk Darma, Balong Cigugur, Balong Dalem, Cibeureum, Cipaniis, Cipaniis Singkup, Telaga Remis, and Telaga Nilem. Meanwhile, other sectors (non-tourism) managed by Perumda Aneka Usaha did not provide profits. With the failure of non-tourism sectors, Perumda Aneka Usaha is declared to experience a recession on the balance sheet of Perumda Aneka Usaha for 2010-2019 because the company's revenue is lower than the annual operating costs. [12]

\subsection{Factors affecting the activities of local companies}

Basically, there are several factors that affect regional policy on the establishment of Perumda Aneka Usaha, both personal and social factors. In this regard, Regional Policy on the establishment of Perumda Aneka Usaha must be based on Kuningan District Regional Regulation No. 11 of 2019 on Perumda Aneka Usaha and must be immediately implemented by creating implementing regulations. Then, officers implementing the policies must carry out their duties properly and honestly, and must understand the purpose of establishing Perumda Aneka Usaha. Next, the existing facilities, including company's mechanism and standard operating procedure (SOP), are expected to be able to support its operations. Finally, society who is the target of these policies will act in response to legal norms as a function of the applicable rules.

The above description is in line with Lawrence Friedman [13] who argues that law as a system is strongly affected by Legal Structure, Legal Substance, and Legal Culture. Referring to this theory, the factors affecting regional policies on the establishment of Perumda Aneka Usaha are:

a. Factor of legal structure, legal structure factor refers to institutions, apparatus, facilities, and infrastructures. In terms of apparatus, it will be related to the human factor that makes the policy, the extent to which the apparatus feels bound by the existing policy, the extent to which the synchronization of the authority given to the apparatus so that they can carry out their authority appropriately, the extent to which the level of capability, integrity, and commitment of the apparatus, the limits to which apparatus are allowed to do discretion in order to make appropriate and contextual decisions, and the kind of role models the apparatus must show to the community. According to Van Doorn,[6] there are several factors attached to the apparatus as a human being, namely factors of personality, social origins, economic interests, political beliefs, and views of life. Facility and infrastructure factors relate to the availability of supporting resources to assist the policy-making process. Basically, there are a number of questions regarding the facilities and infrastructures, including; are the necessary facilities and infrastructure available? are the available 
facilities (equipment, finance, etc.) still adequate and usable? have the existing facilities been used effectively? and what facilities and infrastructures should be prepared to support the policy-making process?

b. Factor of legal substance, legal substance factor relates to the applicable legislations which have binding force and serve as guidelines for law enforcement officers. The shifted status of Mount Ciremai to a National Park (TNGC) based on the Decree of the Minister of Forestry No. 242/Menhut-II/2004 which changed the status of Mount Ciremai from a protected forest to a national park should have been the concern of the regional government when formulating Regional Regulation No. 11 of 2019 as a substitute for Regional Regulation No. 8 of 2009 on the Establishment of Perumda Aneka Usaha. It is because most of the tourism attractions managed by Perumda Aneka Usaha are in the National Park area.

c. Factor of legal culture, according to Friedman, without legal culture, the legal system is inert, a dead fish lying in a basket, not a living fish swimming in its sea. [14] Every society has a different legal culture. Kuningan District society, as other agrarian societies, views tourism as a gift from God that must be preserved. Therefore, the society does not give a positive response when there are efforts to carry out tourism development and industrialization. Kuningan District society has not yet supported a modern and professional tourism management because it is considered contrary to the beliefs and vision of Kuningan as a Conservation District. It is one of the factors inhibiting tourism sector in Kuningan District to be able to develop even though it has a tremendous tourism potential.

\section{Conclusion}

In an effort to increase local own-source revenue, Kuningan District Regional Government issues a Regional Policy on the establishment of Perumda Aneka Usaha based on Regional Regulation No. 8 of 2009 which was amended by Regional Regulation No. 11 of 2019 on Perumda Aneka Usaha. Up to now, Perumda Aneka Usaha has not been able to contribute significantly to the local own-source revenue of Kuningan District. It is because, structurally, its recruitment system of employees and its facilities do not support the company to become professional. Substantially, the shifted status of Mount Ciremai from a protected forest to a national park has narrowed the space for tourist attractions in Kuningan District. Culturally, Kuningan District society has not yet supported a modern and professional tourism management because it is considered contrary to the beliefs and customs of the surrounding community.

\section{References}

[1] Bagir Manan, 1996, Politik Perundang-undangan Dalam rangka Mengantisipasi Liberalisasi Perekonomian, Fakultas Hukum UNIKA, Bandar Lampung, hlm 16

[2] Teuku Ahmad Yani, 2012, Peran Badan Usaha Milik Daerah Dalam Meningkatkan Kesejahteraan Masyarakat, Kanun Jurnal Ilmu Hukum, No. 56 Th. XIV, April 2012, hlm. 119-137

[3] Nasir, Muhammad, Safar, 2019, Analisis Sumber-Sumber Pendapatan Asli Daerah Setelah satu Dekade Otonomi Daerah, Jurnal Dinamika Ekonomi dan Pembangunan, Vol. 2 No. 1, hlm. 30-45 
[4] Heince Jusva Rumende, dkk, 2019, Analisis Kontribusi badan Usaha Milik Daerah Terhadap Pendapatan Asli Daerah Provinsi Sulawesi Utara, Jurnal Pembangunan Ekonomi dan Keuangan Daerah, Vol. 19 No. 9, April 2019, hlm 1-8

[5] Nurmiati, dkk, 2019, Kontribusi Badan Usaha Milik Daerah Terhadap Pendapatan Asli Daerah Kota Makasar, Seminar Nasional Sains, Teknologi, dan Sosial Humaniora, UIT.

[6] Haris Budiman, dkk, Spatial Policy Dilemma: Environmental Sustainability and Economic Growth, Jurnal Untag Law Review, Vol 2, Issue 1, May 2018, hlm 1-9

[7] Antari dan Sedana, 2018, Pengaruh Pendapatan Asli Daerah dan Belanja Modal Terhadap Kinerja Keuangan Pemerintah Daerah, E Jurnal manajemen Unud, Vol. 7 No. 2, hlm 1080- 1110

[8] Badan Pengelolaan Keuangan Daerah Kabupaten Kuningan, Tahun 2019

[9] Bandingkan dengan Penelitian Wan Trisnazilah Sanusi, Perusahaan Daerah Dan Kontribusinya Terhadap Pendapatan Asli Daerah (PAD) Di Kabupaten Natuna Tahun 2012-2014, Jurnal JOM FISIP, Vol 4 No. 2, Oktober 2017, hlm 1-14

[10] Cahyaningrum, Dian, 2018, The Implication of Regional Owned Enterprises Legal Form to Its Management, Jurnal Negara Hukum, Vol. 9 No. 12, hlm. 59-78

[11] Husain Ali, 2019, Dinilai Tak Ada Kontribusi Dewan Usul PDAU Dibubarkan, Radar Cirebon.com, 19 Juni 2019

[12] Nana Sutisna, Re Thinking The Organization Re Engineering For Company and Turn Around Strategy, Sebagai Upaya Strategis Untuk Mewujudkan Perumda Aneka Usaha kabupaten Kuningan Sebagai Perumda Dengan Pengelolaan Terbaik Di Indonesia, Disampaikan Pada Open Bidding Direktur Perumda Aneka Usaha 2020-2024

[13] Lawrence M Friedman, 2015, Sistem Hukum Perspektif Ilmu Sosial, (Terjemahan dari The Legal System: A Social Perspective, New York: RusselSage Foundation, 1975), Penerbit Nusa Media. Bandung

[14] Lawrence Friedman, “American Law”, London: W.W. Norton \& Company, 1984, hlm. 6 